\title{
URGENSI PERLINDUNGAN HUKUM TERHADAP PEREMPUAN DAN ANAK KORBAN KEKERASAN
}

\author{
Dr. Putu Sekarwangi Saraswati, SH, MH. \\ Fakultas Hukum Universitas Mahasaraswati, Jalan Kamboja Nomor 11A Denpasar. \\ (sekarwangisaraswati@gmail.com)
}

\begin{abstract}
Abstrac, Women and children as marginalized people whose existence in Indonesia are many objects of oppression because patrilineal culture makes women and children in Indonesia must be protected specifically in order to get definite and fair legal protection especially to women and children victims of violence, so that not many Indonesian women feel his life is always oppressed and not many children in Indonesia lose their future.
\end{abstract}

Keywords: Women and Children, Patrilineal, Victims of Violence

Abstrak, Perempuan dan anak sebagai kaum termarjinalkan yang keberadaannya di indonesia banyak menjadi objek penindasan karena budaya patrilinear membuat perempuan dan anak di indonesia harus dilindungi secara khusus agar mendapatkan perlindungan hukum yang pasti dan berkeadilan terlebih kepada perempuan dan anak korban kekerasan, sehingga tidak banyak perempuan indonesia yang merasa hidupnya selalu tertindas dan tidak banyak anak-anak di indonesia kehilangan masa depannya.

Kata Kunci: Perempuan dan Anak, Patrilinear, Korban Kekerasan

\section{Pendahuluan}

\subsection{Latar Belakang}

Jumlah penduduk indonesia yang bulan Juli tahun 2019 berjumlah semakin hari semakin meningkat, dengan 268.074.600 Jiwa, yang jumlah tersebut pertumbuhan penduduk yang sangat pesat lebih banyak di dominasi oleh penduduk dan padat membuat berbagai polemic yang berjenis kelamin Laki-Laki yaitu terjadi di indonesia ini. Tercatat dalam data sejumlah 134.000.000 Jiwa, dan anak-anak Badan Pusat Statistik (BPS) Jumlah berjumlah 66,17 Juta Jiwa. hal ini membuat Penduduk Indonesia yang didata pada 
peluang penindasan terhadap perempuan termasuk anak-anak terjadi lebih besar. ${ }^{1}$

Berbagai jenis kasus yang menimpa perempuan dan anak sehingga menjadi korban kekerasan terjadi di indonesia. Yang lumrah orang kenal adalah Kekerasan Dalam Rumah Tangga (KDRT) namun sekarang ini terjadi banyak sekali jenis kekerasan seperti Kekerasan seksual, penelantaran, eksploitasi, perundungan, kekerasan dalam pacarana, pemerkosaan, dan masih banyak lainnya. Kasus-kasus tersebut diatas terjadi baik secara fisik maupun fsikis terhadap perempuan dan anak-anak indonesia.

Dampak terhadap hal tersebut keberlangsungan peran perempuan sebagai isteri, ibu rumah tangga, pengasuh anak, pekerja menjadi terkendala dan menimbulkan dampak-dampak lainnya.

\footnotetext{
${ }^{1} \mathrm{Https} / /$ :www.Bps.go.id. Diakses pada 13 April 2020 Pukul 20:23 Wita

${ }^{2}$ Setiadi danSusi Eja Yuarsi (eds), 2002, Kekerasan terhadap perempuan dalam multi
}

Kemudian hilangnya masa depan anakanak indonesia akibat terjerumus menjadi pelaku maupun korban kekerasan baik karena kehendaknya maupun tereksploitasi atas kepentingan orang lain menjadi mimpi burul terhadap masa depan indonesia.

Negara sebagai organisasi yang berkewajiban menjamin kehidupan masyarakatnya harus selalu berperan aktif untuk melindungi kekerasan terhadap perempuan di indonesia, sehingga tidak ada kesempatan bagi para pelaku untuk melakukan aksinya, menurut para ahli, kekerasan terhadap perempuan adalah perwujudan hubungan kekuasaan yang secara historis timpang, antara perempuan dan laki-laki, baik di tingkat individu maupun masyarakat. ${ }^{2}$

Kekerasan terhadap perempuan secara tegas telah disebutkan dalam konvensi

etnik, pusat studi kependudukan dan kebijakan UGM, Yogyakarta. 
penghapusan segala bentuk diskriminasi terhadap perempuan CEDAW yang berlaku sejak tahun 1981. Yang kemudian diratifkasi oleh indonesia dalam UndangUndang Nomor 7 Tahun 1984 Tentang Pengesahan segala bentuk diskriminasi terhadap perempuan. Kemudian dunia juga telah menyepakati tentang Konvensi hakhak anak, yaitu konvensi yang mengatur hak-hak sipil, politik, ekonomi, social, dan kultural anak-anak yang mulali berlaku pada 2 September $1990 .^{3}$

Dalam hukum indonesia untuk menindak lanjuti terkait konvensi tersebut guna melindungi segenap warga negara terlebiuh perempuan dan anak indonesia menggundangkan Undang-Undang Nomor 23 Tahun 2004 tentang Penghapusan Kekerasan dalam Rumah Tangga, ${ }^{4}$ dan

\footnotetext{
${ }^{3}$ Article Uniten Nation Treaty Collection, diakses pada tanggal 13 April 2020 Pukul 20:48 Wita.
}

Undang-Undang Nomor 23 Tahun 2002

Tentang Perlindungan anak.

Undang-Undang yang menyatakan
penghapusan kekerasan terhadap
kekerasan dalam rumah tangga
menjelaskan dalam bagian menimbang
dalam huruf c bahwa:

"bahwa korban kekerasan dalam rumah tangga, yang kebanyakan adalah perempuan, harus mendapatkan perlindungan dari negara dan/atau masyarakat agar terhindar dan terbebas dari kekerasan atau ancaman kekerasan, penyiksaan, atau perlakuan yang merendahkan derajat dan martabat kemanusiaan"

Dari penjelasan diatas jelas maksud darii negara adalah untuk melindungi perempuan agar tidak terjadinya penindasan dan bentuk-bentuk lainnya, bahkan tidah hanyak tertuju pada kasus KDRT tetapi juga kekerasan lainnya.

Selanjutnya dalam bagian menimbang Undang-Undang Nomor 23 Tahun 2002

\footnotetext{
${ }^{4} \mathrm{Https} / /$ :www.kemenppa.go.id diakses pada tanggal 13 April 2020 Pukul 20:56Wita.
} 
Tentang Perlindungan Anak dalam huruf c dijelaskan Bahwa:

"bahwa anak adalah tunas, potensi, dan generasi muda penerus cita-cita perjuangan bangsa, memiliki peran strategis dan mempunyai ciri dan sifat khusus yang menjamin kelangsungan eksistensi bangsa dan negara pada masa depan;"

Dari penjelasan diatas bahwa anak-anak indonesia disiapkan untuk menjadi generasi penerus yang berkualitas, sehingga tidak boleh terjerumus menjadi korban kekerasan atau korban kejahatan. Namun dari penjelasan peraturanperaturan diatas, belum terdapat secara spesifik peraturan mengatur mengenai bagaimana negara menjamin keberadaan para perempuan dan anak korban kekerasan di Indonesia.

\section{Rumusan Masalah}

1. Bagaimana Perlindungan Perempuan dan Anak di Indonesia?

2. Bagaimana Urgensi Perlindungan Perempuan dan Anak Korban Kekerasan di Indonesia?

\subsection{Tujuan}

Untuk mengetahui pengaturan terhadap perlindungan perempuan dan anak di indonesia, serta mengetahui urgensi pengaturan perlindungan perempuan dan anak korban kekerasan.

\section{Pembahasan}

\subsection{Perlindungan Perempuan dan Anak}

\section{di Indonesia}

Indonesia sebagai negara hukum (rule of law) menjamin setiap warga negaranya untuk selalu mendapatkan perlakuan yang sama di hadapan hukum yang secara equal diatur dalam Undang-Undang dasar Negara Republik Indonesia 1945 pasal 1 ayat 3 , yang menjelaskan bahwa negara indonesia adalah negara hukum.

Sebagai negara hukum indonesia harus senantiasa memberikan kepastian terhadap segala tindakan yang dilakukan oleh warga negaranya, baik itu perempuan atau laki-laki, 
anak-anak atau orang tua. Karena hal tersebut negara harus selalu ada untuk masyarakat, termasuk ketika terjadi permasalahan hukum didalamnya.

Dalam menjamin perlindungan perempuan dan anak, negara telah menyiapkan beberapa regulasi, Lembaga dan kebijakan lain yang mendukung terpenuhinya hak-hak perempuan dan anak di indonesia. Sehingga melalui aturan-aturan hukum tersebut, serta Lembaga yang ada, pemerintah turut sera dalam memperhatikan warga negaranya sesuai amanat konstitusi.

Dari segi hukum, pemerintah telah membentuk aturan mengenai perlindungan perempuan dari kekerasan dalam rumah tangga yaitu Undang-Undang Nomor 23 Tahun 2002 yang mengatur secara spesifik bagaimana hukum melindungi peremuan jika terjadi kekrasan dalam rumah tangga. Dalam perlindungan terhadap anak-anak negara mengeluarkan Undang-Undang Nomor 23 Tahun 2004 Tentang Perlindungan Anak untuk melindungi setiap generasi muda bangsa dari tindakan-tindakan kekerasan baik fisik maupun psikis.

Guna melaksanakan aturan-atura tersebut diatas, pemerintah membentuk Lembaga yang berdasar pada Undang-Undang Kementerian Negara Nomor 39 Tahun 2008, yang bertugas untuk mengatur tentang kedudukan, tugas pokok, fungsi, susunan organisasi, pembentukan, pengubahan, menggabungkan, memisakhan, dan/atau mengganti, pembubaran/menghapus kementerian. Melalui undang-undang tersebut pemerintah membentuk Kementerian Pemberdayaan Perempuan dan perlindungan Anak (kemen PPPA) 
yang bertugas untuk

menyelenggarakan pemeintahan dalam

bidan pemberdayaan perempuan dan perlindungan anak untuk membantu presiden dalam menyelenggarakan pemerintahan. $^{5}$

Kemen PPPA selanjutnya membawahi beberapa Lembaga di daerah yaitu Dinas Pemberdayaan Perempuan dan Perlindungan Anak (DP3A), Komisi Perlindungan Anak Daerah (KPAD), P2TP2A. selain Lembaga-lembaga tersebut juga terdapat Lembaga Bantuan Hukum yang ada untuk memberikan Perlindungan Terhadap Perempuan dan Anak.

Kelembagaan tersebut masingmasing bertugas untuk memberikan pemberdayaan terhadap perempuan dan perlindungan anak baik dari pusat, provinsi maupun daerha kabupaten/kota, bahkan desa yang didalamnya terdapat Lembaga PKK. Sehingga melalui Lembaga-lembaga diatas pemerintah menjamin setiap perempuan dan anak-anak indonesia terlindungi.

\subsection{Urgensi Perlindungan Perempuan dan Anak Korban Kekerasan di Indonesia}

Perempuan dan anak merupakan kelompok yang perlu mendapatlan perlindungan, karena sistem social budaya dan kondisi fisiknya. Banyak kontribusi yang perempuan berikan dalam kehidupan sehari-harinya namun sering kali mereka menjadi warga negara yang di nomor dua dan terabaikan. Mereka seakan-akan karena status secara jenis kelamin maupun gendernya. Karena hal tersebut perlu dilakukan penguatan kemampuan dan

\footnotetext{
${ }^{5}$ https://www.Kemenpppa.go.id Diakses pada 14 April 2020 Pukul 20:35 Wita
} 
persamaan hak berdasarkan pada keadilan gender dalam masyarakat.

Untuk memahami pengertian perempuan tidak bisa lepas dari persoalan gender dan sex, dalam konteks gender perembuan bersifat feminism, sedangkan dalam sex peremuan dikaitkan dengan jenis kelamin. $^{6}$

Berkaitan dengan keadaan hidup perempuan dan anak-anak yang temarjinalkan di indonesia, diikuti dengan perkembangan peningkatan tindakan kekerasan terhadap perempuan dan anak masing sangat memerlukan perhatian yang lebih dari pemerintah. Banyak perempuan korban kekerasan masih banyak yang enggan melaporkan perlakuak kekerasan yang menimpanya dengan berbagai alas an:

\footnotetext{
${ }^{6}$ https://www.referensimakalah.com diakses pada 14 April 2020 Pukul 21:14 Wita

${ }^{7}$ Jurnal Perlindungan Perempuan dan Anak Korban Kekerasan Melalui Penyusunan
}

1. Adanya rasa malu fisik maupun psikis untuk melaporkan kasusnya ke apparat berwenang

2. Adanya rasa kasian kepada suami ketika melaporkan kasus tersebuut

3. Ketakutan adanya balasan ketika melaporkan kasus tersebut kepada pihak berwenang

4. Adanya keragu-raguan bahwa masalahnya akan dapat terselesaikan

5. Kurang pemahaman masyarakat mengenai cara dan kemana dapat melapor

6. Kesulitan secara ekonomi

7. Kekawatiran tidak dapat merawat anak-anak dengan baik, tanpa adanya suami. $^{7}$

Hal tersebut yang menjadi alas an masih banyaknya kasus kekerasan yang belum mendapatkan perhatian dari pemerintah.

peraturan daerah, Universitas Udayana, Hal. 11. 
Seiring dengan peraturan yang

dikeluarkan pemerintah, lembga-lembaga yang dibentuk, anggaran yang disiapkan dan sebagainya, faktanya kekerasan trehadap perempuan dan anak terjadi terus meningkat. Berkaitan dengan hal tersebut dapat dilihat terdapat ketidak efektifan salah satu atau keseluruhan bagian dari cara-cara pemerintah untuk melindungi warga perempuan dan anak di indonesia.

Berdasarkan pada tingkat efektivitas yang kurang tersebut, setidaknya pemerintah dapat lebih memastikan semua regulasi dapat berjalan dengan baik dan dipernakna oleh setiap Lembaga. Menelisik pada peraturan diatas, belum terdapat secara sepesifik pemerintah memberikan perlindungan kepada perempuan dan anak korban kekerasan. Perlakuan terhadap perempuan dan anak korban kekerasan tidak dapat disamakan dengan perlindungan pada kaum laki-laki, sesuai dengan Undang-Undang Nomor 13
Tahun 2006 Tentang Perlindungan Saksi dan Korban. Untuk itu sekiranya pemerintah perlu menerbitkan secara khusus aturan yang mengatur bagaimana menangani perempuan dan anak korban kekerasan yang terjadi, baik di pusat maupun daerah, melalui peran Lembaga pembuat peraturan perundang-undangan. Sehingga peningkatan terhadap kasus kekerasan terhadap perempuan dan anak korban kekerasan dapat diminimalisir atau bahkan di hapuskan.

\section{Penutup}

\subsection{Simpulan}

Urgensi perlindungan perempuan dan anak korban kekerasan melalui penyusunan peraturan perundangundangan baik di pusat maupun daerah perlu dilakukan untuk memberikan perlindungan kepada korban tindak kekerasan bagi perempuan dan anak. 


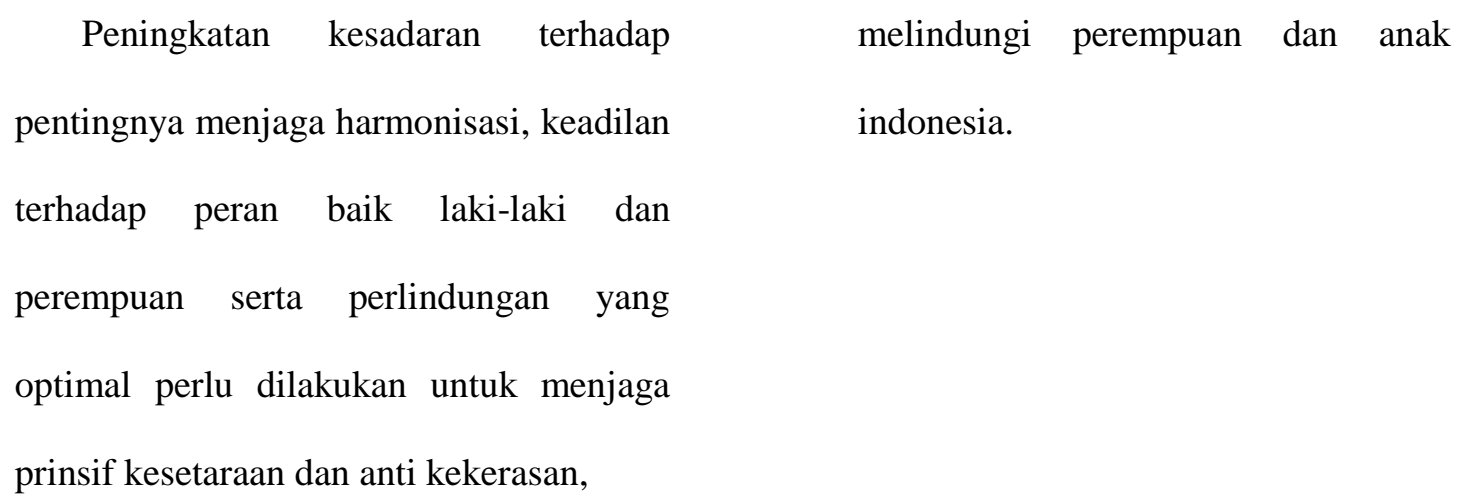

\subsection{Saran}

1. Agar pemerintah segera merancang peraturan perundang-undangan secara khsus mengenai perlindungan perempuan dan anak korban kekerasan

2. Memaksimalkan segala bentuk regulasi yang ada serta peran-peran Lembaga terkait untuk sama-sama

\section{Daftar Pustaka}

\section{Buku}

Setiadi danSusi Eja Yuarsi (eds), 2002, Kekerasan terhadap perempuan dalam multi etnik, pusat studi kependudukan dan kebijakan UGM, Yogyakarta.

\section{Jurnal}

Jurnal Perlindungan Perempuan dan Anak Korban Kekerasan Melalui Penyusunan peraturan daerah, Universitas Udayana. 


\section{Peraturan Perundang-undangan}

Undang-Undang Nomor 23 Tahun 2004 Tentang Perlindungan Terhadap Kekerasan Dalam Rumah Tangga

Undang-Undang Nomor 23 Tahun 2002 Tentang Perlindungan Anak

Undamg-Undang Nomor 13 Tahun 2006 Tentang Perlindungan Saksi dan Korban

\section{Internet}

Article Uniten Nation Treaty Collection.

Https//:www.Bps.go.id.

Https//:www.kemenppa.go.id

https://www.Kemenpppa.go.id

https://www.referensimakalah.com 